NOTE

\title{
Nutrient recycling by coastal macrofauna: intra- versus interspecific differences
}

\author{
Sébastien Villéger ${ }^{1,2, *}$, Franck Ferraton ${ }^{1}$, David Mouillot ${ }^{1,3}$, Rutger de Wit $^{1}$ \\ ${ }^{1}$ Laboratoire Ecologie des systèmes marins côtiers, UMR 5119 Université Montpellier 2, Centre National de la Recherche \\ Scientifique (CNRS)-Institut de Recherche pour le Développement (IRD), Institut Français de Recherche pour l'Exploitation \\ de la Mer (IFREMER), Université Montpellier 1, Université Montpellier 2, CC 093, 34095 Montpellier, France \\ ${ }^{2}$ Laboratoire Evolution et Diversité Biologique, UMR 5174 CNRS-UPS, Université Paul Sabatier, 118 Route de Narbonne, \\ 31062 Toulouse Cedex 4, France \\ ${ }^{3}$ Australian Research Council (ARC) Centre of Excellence for Coral Reef Studies, James Cook University, Townsville, \\ Queensland 4811, Australia
}

\begin{abstract}
In the context of global change, improving our understanding of how species communities shape ecosystem functioning and stability is a key issue. Therefore, we have to adopt a functional approach by considering the role of organisms in ecosystem processes. Nutrient recycling is important for sustaining primary productivity in aquatic systems but has been largely overlooked for macro-organisms. In a Mediterranean coastal ecosystem we found that per capita ammonium and phosphate excretion rates for the 9 dominant nektonic macrofauna species exceeded those of 3 benthic bivalves by factor 100. Body mass and species identity together significantly explained these interspecific differences in excretion rates. Significant differences in the effect of body mass on nutrient excretion rates were also found among the 7 fish species. More studies are needed to further explore the biological determinants of the intra- and interspecific variability of excretion rates as well as their consequences on marine ecosystem functioning.
\end{abstract}

KEY WORDS: Excretion · Ammonium $\cdot$ Phosphate $\cdot$ Fish $\cdot$ Functional diversity $\cdot$ Benthos $\cdot$ Nekton $\cdot$ Thau lagoon Resale or republication not permitted without written consent of the publisher

\section{INTRODUCTION}

Coastal ecosystems, including estuaries and lagoons, sustain key services but are severely affected by human activities (Barbier et al. 2011). Changes in environmental conditions (e.g. global warming, eutrophication), in addition to direct exploitation of resources (e.g. fish, bivalves), modify the biodiversity of coastal communities (e.g. Villeger et al. 2010), which, in turn, affects ecosystem functioning and stability (Raffaelli et al. 2003, Solan et al. 2004, Worm et al. 2006, Bracken et al. 2008). Therefore it is urgent to better assess the diversity of species roles in coastal ecosystems. Indeed, the functional diversity of spe- cies communities is likely to be a better predictor than species richness per se for the effect of communities on coastal ecosystem functioning (Waldbusser et al. 2004).

Coastal macrofauna is marked by a large taxonomic diversity with several phyla of invertebrates and several classes of vertebrates. All these heterotrophic organisms ingest food (alive or dead). Via the digestion process a small part of it is assimilated into biomass while the major part is catabolised for the generation of energy. Catabolic waste products are excreted mainly as ammonium and phosphate, into the water column (Wright 1995, Vanni 2002). Thus, aquatic macrofauna contributes to nutrient cycling 
by transferring the essential elements nitrogen $(\mathrm{N})$ and phosphorus (P), bound in the organic matter of living organisms and detritus, into the inorganic pool available to primary producers (Dame et al. 1991, Cockcroft \& McLachlan 1993, Vanni 2002).

Nutrient recycling by macrofauna has been widely investigated in freshwater ecosystems (e.g. Vanni 2002, Vanni et al. 2002, Hood et al. 2005, Torres \& Vanni 2007, McIntyre et al. 2008), while only few studies have focused on marine ecosystems (Meyer \& Schultz 1985, Haertel-Borer et al. 2004, Layman et al. 2011). Organisms differ in their ability to recycle nutrients (Vanni et al. 2002, Hood et al. 2005), as a result of the imbalance between their diet (i.e. food quality and quantity) and their requirement for growth (i.e. $\mathrm{N}$ and $\mathrm{P}$ contents of their biomass, and growth efficiency). These interspecific differences in recycling ability coupled to species biomass determine the role of each species in ecosystemwide nutrient cycling (e.g. McIntyre et al. 2008, Layman et al. 2011). In the context of marine biodiversity loss (Worm et al. 2006, Bracken et al. 2008), it is thus crucial to obtain knowledge of respective abilities of coastal macro-organisms to recycle nutrients, particularly $\mathrm{N}$ and $\mathrm{P}$, which are the most important for primary production (Elser et al. 2007) and which ultimately sustain fisheries catches (Chassot et al. 2010).

Here we explored, through the measure of excretion fluxes, the ability of dominant macrofaunal species to recycle nitrogen and phosphorus in a coastal marine lagoon. We then tested and explained intraand interspecific differences in ammonium and phosphates excretion rates using biological traits.

\section{MATERIALS AND METHODS}

\section{Sampling}

The experiment was carried out in a shallow lagoon at the French Mediterranean coast (Thau lagoon, $\left.43^{\circ} 26^{\prime} 51^{\prime \prime} \mathrm{N}, 3^{\circ} 39^{\prime} 6^{\prime \prime} \mathrm{E}\right)$. We only targeted the species present in the littoral habitats of this lagoon. Nektonic species were sampled using a beach seine (length: $25 \mathrm{~m}$; height: $1.2 \mathrm{~m}$; stretched mesh: $12 \mathrm{~mm}$ ). Benthic mollusks were picked by hand in the substrate near the shoreline (depth $<0.5 \mathrm{~m}$ ).

The experiment was conducted between 23 June and 3 July 2009. Air temperature was $26^{\circ} \mathrm{C}$ in the morning to $35^{\circ} \mathrm{C}$ in the afternoon. Water temperature varied between 28 and $30^{\circ} \mathrm{C}$. Salinity was $35 \mathrm{psu}$.

A total of 521 individuals belonging to 12 species was collected (Table 1). These species included 3 bivalves, 1 cephalopod, 1 crustacean (shrimp), and 7 fishes (representing 7 families). Overall, the sampled individuals were small (Table 1), being either adults of small species (e.g. mollusks, shrimp, goby) or juveniles of migratory larger species (seabream, mullet).

\section{Nutrient excretion rates}

The general protocol used to assess nutrient excretion by macro-organisms follows that of Vanni et al. (2002). Captured specimens were placed in plastic bags filled with filtered $(5 \mu \mathrm{m})$ and UV-sterilized seawater (from the IFREMER Palavas aquaculture research station) and stored at the lagoon water temperature. Use of seawater with very low concentra-

Table 1. Species studied and experiment settings. For the experimental specimens, the mean body mass \pm SD and the range (in parentheses) are given

\begin{tabular}{|c|c|c|c|c|c|c|c|}
\hline Species & Class & Family & $\begin{array}{l}\text { No. of ind. } \\
\text { per replicate }\end{array}$ & $\begin{array}{l}\text { No. of } \\
\text { replicates }\end{array}$ & $\begin{array}{l}\text { Body mass } \\
\text { (g) }\end{array}$ & $\begin{array}{l}\text { Time } \\
(\min )\end{array}$ & $\begin{array}{l}\text { Volume of } \\
\text { water (l) }\end{array}$ \\
\hline Cerastoderma edule & Bivalvia & Cardiidae & $3-5$ & 15 & $2.4 \pm 0.2(1.5-4.5)$ & $51 \pm 2$ & 0.5 \\
\hline Loripes lacteus & Bivalvia & Lucinidae & 20 & 14 & $0.3 \pm 0.01(0.2-0.4)$ & $57 \pm 3$ & 0.5 \\
\hline Ruditapes decussatus & Bivalvia & Veneridae & 5 & 14 & $2.7 \pm 0.2(1.6-4.4)$ & $56 \pm 3$ & 0.5 \\
\hline Sepiola affinis & Cephalopoda & Sepiolidae & 1 & 2 & $0.7 \pm 0.4(0.3-1.1)$ & $98 \pm 25$ & 0.5 \\
\hline Palaemon serratus & Malacostraca & Palaemonidae & 1 & 6 & $1.2 \pm 0.1(0.8-1.6)$ & $75 \pm 7$ & 1 \\
\hline Atherina boyeri & Actinopterygii & Atherinidae & 5 & 3 & $1.9 \pm 0.2(1.6-2.2)$ & $66 \pm 2$ & 5 \\
\hline Liza aurata & Actinopterygii & Mugilidae & 1 & 14 & $4.1 \pm 0.2(3.3-6.4)$ & $70 \pm 4$ & 2 \\
\hline Pomatoschistus microps & Actinopterygii & Gobiidae & 1 & 9 & $4.4 \pm 0.6(2.1-7.8)$ & $69 \pm 6$ & 2 \\
\hline Salaria pavo & Actinopterygii & Bleniidae & 1 & 13 & $4.3 \pm 0.4(2.3-6.8)$ & $77 \pm 4$ & 2 \\
\hline Sparus aurata & Actinopterygii & Sparidae & 1 & 11 & $3.8 \pm 0.2(3.0-4.9)$ & $70 \pm 4$ & 2 \\
\hline Symphodus cinereus & Actinopterygii & Labridae & 1 & 13 & $6.5 \pm 1.0(2.8-14.8)$ & $73 \pm 4$ & 2 \\
\hline Syngnathus abaster & Actinopterygii & Syngnathidae & 1 & 3 & $0.6 \pm 0.1(0.5-0.7)$ & $78 \pm 3$ & 1 \\
\hline
\end{tabular}


tion of micro-organisms prevents bias in estimation of nutrient excretion rates by macro-organisms (Vanni 2002). Bag volume depended on species size, and ranged from 0.5 to 21 (Table 1). These plastic bags were then bound between 2 floating tubes (polystyrene foam) and immediately immersed in a big plastic tank filled with lagoon water and set up in the lagoon. Thus, water temperature inside the bags was kept at that of lagoon water. A clean glass plate (diameter: $18 \mathrm{~cm}$ ) was placed inside each bag as a support for the benthic species.

Individuals were kept in the bags for $\sim 1 \mathrm{~h}$ (Table 1). This length of time and the volume of water were determined to ensure that final nutrient concentrations in the water were sufficient to be accurately measured and that starvation time was negligible (Whiles et al. 2009). The chosen volume was too large for measuring excretion rates of individual bivalves. Therefore, 3, 5, and 20 individuals of Cerastoderma edule, Ruditapes decussates, and Loripes lacteus, respectively, were placed in the bags (Table 1). Atherina boyeri individuals kept alone in plastic bags died after a few minutes, probably because of the stress. For this pelagic fish species, we carried out 3 replicates with 5 individuals each using plastic buckets filled with 51 of filtered seawater and immersed in the lagoon. For other species, no obvious signs of stress were observed.

Although experimental conditions may induce bias through stress by change in locomotion or feeding activities, this method is known to be reliable to assess excretion rates, since no strong discrepancies have been observed between this field method and the predicted rates using bioenergetic models (Vanni 2002).

Specimens were removed from bags and weighed using an electronic balance (0.1 g precision). Mollusks were dissected prior to weighting and only flesh wet mass was considered. The ambient water from the bag containing the excretions of the specimen was immediately filtered using a Whatman GF/F filter (pore size $0.45 \mu \mathrm{m}$ ) and stored in an icebox before being frozen in the lab. After thawing, the water of each sample was then analyzed for ammonium $\left(\mathrm{NH}_{4}{ }^{+}\right)$and orthophosphate $\left(\mathrm{PO}_{4}{ }^{3-}\right)$ with indophenol-blue and phosphomolybdate colorimetric methods, respectively (Aminot \& Kerouel 2004) using a UV-visible light spectrophotometer (Cary 100; Varian).

During each series of incubations, 2 replicates of 11 of filtered seawater were left $\sim 1 \mathrm{~h}$ in a plastic bag and then sampled as a control for potential contamination by air or handling.
Per capita excretion rates (ER) for ammonium and phosphate ( $\mu \mathrm{mol}$ ind..$^{-1} \mathrm{~h}^{-1}$ ) were computed for each replicate as follows (Vanni et al. 2002):

$$
\mathrm{ER}_{\mathrm{I}}=\frac{I_{\text {bag }}-I_{\text {control }}}{V \times t \times n}
$$

with $V$ being the volume (l) of the water in the plastic bag and $t$ the time (h) that the $n$ individual(s) stayed in it.

$I_{\text {bag }}$ is the final concentration of ion $I$ in the water $\left(\mu \mathrm{mol} \mathrm{l}{ }^{-1}\right.$ ) and $I_{\text {control }}$ the final concentration observed for the control.

We also computed mass-specific excretion rates by dividing per capita excretion rates by body mass of individuals (Vanni et al. 2002). These variables correspond to the molar amount of ammonium and phosphate excreted by organisms per unit body mass and per unit time, thus allowing us to compare nutrient cycling ability of species having different masses (Meyer \& Schultz 1985, Vanni et al. 2002). Body mass and excretion rates generally exhibit a large range, and we thus scaled them using a $\log _{10}$ transformation (Vanni et al. 2002).

\section{Statistical analyses}

The linear relationship between $\log _{10}$-transformed per capita excretion rate and the $\log _{10}$-transformed mean body mass of individuals present in each replicate was tested using linear models (LM) for each species and each nutrient (Fox 2008). The interspecific differences in per capita excretion rates were tested using the non-parametric Kruskal-Wallis test.

Then we tested how several biological factors contributed to the differences in mass-specific excretion rates. To this aim we used generalized boosted models (GBM; function 'gbm' from the gbm R library). The GBM method belongs to the boosted regression tree (BRT) family and uses 2 algorithms: regression trees and the stochastic gradient boosting technique (Friedman 2001). This method tests all the combinations of factors and provides, for each factor, the percentage of significant models that take it into account. The advantage of GBM over linear multiregression models is that they make no assumption of linearity and are thus efficient for the detection of threshold effects of factors. This recent method has been successfully applied in ecology (e.g. Jalabert et al. 2010). GBM analyses were carried out on ammonium and phosphate excretion rates using body mass (log transformed), species identity, taxonomic class (bivalve, crustacean, cephalopod, fish), life-stage 
(juvenile or adult), and time of incubation as predictive variables. To illustrate the results of these GBM, we performed regression tree analyses (using the function 'tree' from the tree R library).

\section{RESULTS}

We carried out the excretion experiment on 148 replicates. A total of 23 replicates showed no $\mathrm{PO}_{4}{ }^{3-}$ as the measured signal was below the limit of detection $\left(0.1 \mu \mathrm{mol} \mathrm{l}^{-1}\right)$. Using a selection based on inter- quartile range, 8 replicates were detected as outliers compared to the replicates of the same species. These 31 replicates were removed prior to statistical analyses which were thus conducted on 117 replicates (Fig. 1).

Per capita excretion rates show intraspecific variability for both ammonium and phosphate (Fig. 1). However, this intraspecific variability was globally lower than interspecific differences for ammonium and phosphate per capita excretion rates (KruskalWallis test on $\log _{10}$-transformed values; $\mathrm{df}=11$, $\mathrm{p}<$ 0.001 for both nutrients).
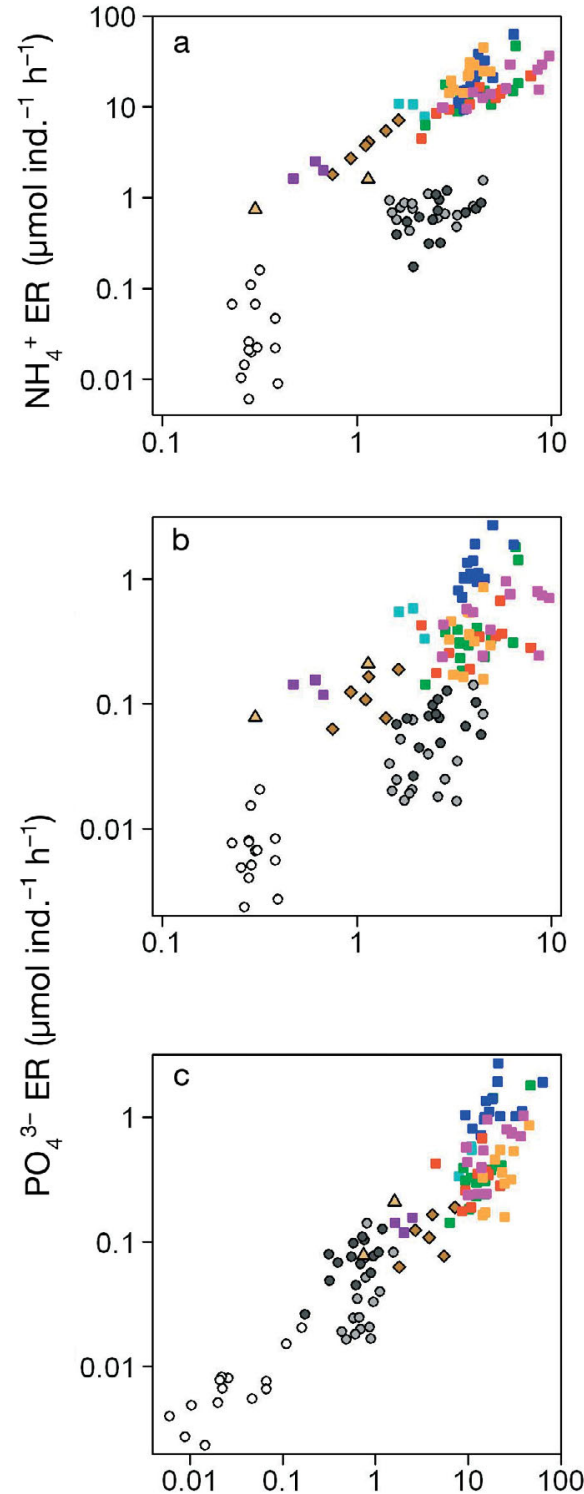

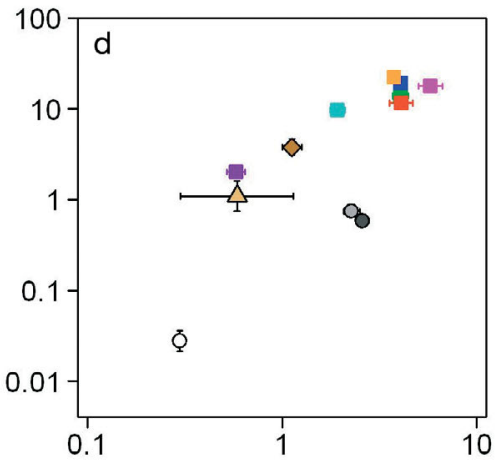

Mass (g)

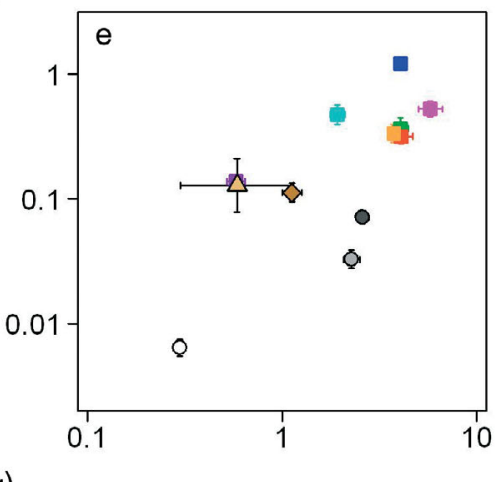

Mass (g)

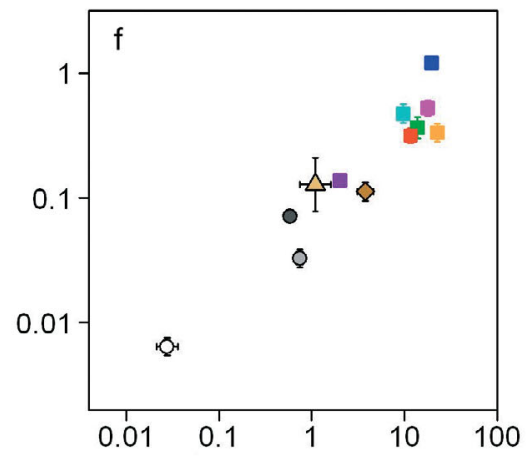

$$
\begin{aligned}
& \text { - Cerastoderma edule } \\
& \text { - Loripes lacteus } \\
& \text { - Ruditapes decussatus } \\
& \text { - Sepiola affinis } \\
& \text { - Palaemon serratus } \\
& \text { - Atherina boyeri } \\
& \text { - Liza aurata } \\
& \text { - Pomatoschistus microps } \\
& \text { - Salaria pavo } \\
& \text { - Sparus aurata } \\
& \text { - Symphurus cinereus } \\
& \text { - Syngnathus abaster }
\end{aligned}
$$

$\mathrm{NH}_{4}^{+}$ER $\left(\mu \mathrm{mol}\right.$ ind. $\left.{ }^{-1} \mathrm{~h}^{-1}\right)$

Fig. 1. $(\mathrm{a}, \mathrm{b}, \mathrm{c})$ Relation between body mass and per capita ammonium $\left(\mathrm{NH}_{4}{ }^{+}\right)$and phosphate $\left(\mathrm{PO}{ }_{4}{ }^{3-}\right)$ excretion rate $(\mathrm{ER})$. $(\mathrm{d}, \mathrm{e}, \mathrm{f})$ Means (and associated SEs) by species 
For both nutrients, relationships between organism body mass and per capita excretion rate were significant $\left(\log _{10}\right.$-transformed values, Spearman's rank test: $\rho=0.812, \mathrm{p}<0.001$ for ammonium; $\rho=0.744, \mathrm{p}<$ 0.001 for phosphates). Similar analyses carried out only on fish revealed a weaker positive correlation between individual body mass and ammonium $(\rho=$ $0.714, \mathrm{p}<0.001)$ or body mass and phosphate $(\rho=$ $0.398, \mathrm{p}<0.001$ ) excretion rates. The correlation between the 2 nutrient excretion rates was significantly positive $(\rho=0.894, \mathrm{p}<0.001)$ but was also lower $(\rho=$ $0.522, \mathrm{p}<0.001$ ) when considering only fish.

Linear model analyses at the intraspecific level revealed a significant positive effect of body mass on the ammonium excretion rate for 5 fish species and for the shrimp Palaemon serratus (Table 2). Body mass had a significant positive effect on the phosphate excretion rate for only 2 species: the blenny Salaria pavo and the mullet Liza aurata (Table 2).

Generalized boosted models demonstrate the predominance of the species factor on the level of both ammonium and phosphate excretion rates. The body mass and class factors play a role in less than one- fourth of the models (Table 3). Time of experiment and life-stage (i.e. adult or not) affected excretion rates only marginally.

Finally, the regression tree discriminated 2 large groups for the ammonium excretion rate (Fig. 2). The 4 mollusks species have lower rates than the shrimp and the 8 fishes. This latter group is split only by body mass. Similarly, phosphate excretion rate was

Table 3. Generalized Boosted Models explaining ammonium $\left(\mathrm{NH}_{4}{ }^{+}\right)$and phosphate $\left(\mathrm{PO}_{4}{ }^{3-}\right)$ excretion rates $\left(\log _{10^{-}}\right.$ transformed values). Values (explanatory variables are ranked by decreasing order of importance) are percentages of significant models that account for the factor considered among all the models tested

\begin{tabular}{|lcc|}
\hline \multirow{2}{*}{ Factor } & \multicolumn{2}{c|}{ Excretion rate } \\
& $\mathrm{NH}_{4}{ }^{+}$ & $\mathrm{PO}_{4}{ }^{3-}$ \\
\hline Species & 60.75 & 69.94 \\
Body mass $\left(\log _{10}\right)$ & 24.30 & 16.62 \\
Class & 14.89 & 12.53 \\
Time & 0.06 & 0.85 \\
Life-stage & $<0.01$ & 0.06 \\
\hline
\end{tabular}

Table 2. Ammonium $\left(\mathrm{NH}_{4}{ }^{+}\right)$and phosphate $\left(\mathrm{PO}_{4}{ }^{3-}\right)$ excretion rates $\left(\mathrm{ER}_{i}\right.$ means $\left.\pm \mathrm{SD}\right)$ for the studied species. The first 2 columns present per capita ER. The third to eighth columns present coefficients estimates (and associated SEs) and goodness of fit of the linear regressions: $\log _{10}(\mathrm{ER})=a+b \times \log _{10}$ (mass). Statistically significant models are in bold $(\mathrm{p}<0.05)$. The last 2 columns present mass-specific excretion rates

\begin{tabular}{|c|c|c|c|c|c|c|c|c|c|c|}
\hline \multirow[t]{2}{*}{ Species } & \multicolumn{2}{|c|}{$\begin{array}{c}\text { Per capita ER } \\
\left(\mu \mathrm{mol} \mathrm{h}{ }^{-1}\right)\end{array}$} & \multirow[t]{2}{*}{ a (SE) } & \multirow[t]{2}{*}{$\begin{array}{l}-\mathrm{NH}_{4}^{+} \\
\quad \mathrm{b}(\mathrm{SE})\end{array}$} & \multirow[t]{2}{*}{$\mathrm{R}^{2}$} & \multirow[t]{2}{*}{ a (SE) } & \multirow[t]{2}{*}{$\begin{array}{l}-\mathrm{PO}_{4}{ }^{3-} \\
\quad \mathrm{b}(\mathrm{SE})\end{array}$} & \multirow[t]{2}{*}{$\mathrm{R}^{2}$} & \multicolumn{2}{|c|}{$\begin{array}{l}\text { Mass-specific ER } \\
\quad\left(\mu \mathrm{mol} \mathrm{g} \mathrm{g}^{-1} \mathrm{~h}^{-1}\right)\end{array}$} \\
\hline & $\mathrm{NH}_{4}^{+}$ & $\mathrm{PO}_{4}^{3-}$ & & & & & & & $\mathrm{NH}_{4}^{+}$ & $\mathrm{PO}_{4}{ }^{3-}$ \\
\hline $\begin{array}{l}\text { Cerastoderma } \\
\text { edule }\end{array}$ & $0.78 \pm 0.07$ & $0.04 \pm 0.01$ & $-0.19(0.09)$ & $0.18(0.24)$ & 0.04 & $-1.77(0.18)$ & $0.80(0.46)$ & 0.19 & $0.15 \pm 0.04$ & $0.03 \pm 0.00$ \\
\hline $\begin{array}{l}\text { Loripes } \\
\text { lacteus }\end{array}$ & $0.04 \pm 0.01$ & $0.01 \pm 0.00$ & $-1.63(0.93)$ & $-0.14(1.75)$ & 0.00 & $-2.25(0.56)$ & $-0.11(1.05)$ & 0.00 & $0.36 \pm 0.04$ & $0.02 \pm 0.00$ \\
\hline $\begin{array}{l}\text { Ruditapes } \\
\text { decussatus }\end{array}$ & $0.66 \pm 0.08$ & $0.08 \pm 0.01$ & $-0.63(0.20)$ & $0.95(0.46)$ & 0.26 & $-1.31(0.17)$ & $0.39(0.39)$ & 0.08 & $0.25 \pm 0.03$ & $0.03 \pm 0.00$ \\
\hline $\begin{array}{l}\text { Sepiola } \\
\text { affinis }\end{array}$ & $1.17 \pm 0.43$ & $0.14 \pm 0.07$ & & & & & & & $1.95 \pm 0.54$ & $0.22 \pm 0.04$ \\
\hline $\begin{array}{c}\text { Palaemon } \\
\text { serratus }\end{array}$ & $4.18 \pm 0.79$ & $0.12 \pm 0.02$ & $0.49(0.01)$ & $1.75(0.06)$ & 0.99 & $-0.99(0.08)$ & $0.85(0.63)$ & 0.32 & $3.43 \pm 0.29$ & $0.10 \pm 0.01$ \\
\hline $\begin{array}{l}\text { Atherina } \\
\text { boyeri }\end{array}$ & $9.82 \pm 0.98$ & $0.49 \pm 0.08$ & $1.29(0.17)$ & $-1.05(0.59)$ & 0.76 & $0.12(0.36)$ & $-1.56(1.24)$ & 0.61 & $5.22 \pm 0.91$ & $0.26 \pm 0.06$ \\
\hline $\begin{array}{l}\text { Liza } \\
\text { aurata }\end{array}$ & $22.26 \pm 3.78$ & $1.29 \pm 0.15$ & $-0.25(0.27)$ & $2.54(0.45)$ & 0.73 & $-0.80(0.28)$ & $1.44(0.45)$ & 0.46 & $5.13 \pm 0.57$ & $0.31 \pm 0.03$ \\
\hline $\begin{array}{l}\text { Pomatoschistus } \\
\text { microps }\end{array}$ & $12.65 \pm 1.72$ & $0.34 \pm 0.05$ & $0.44(0.10)$ & $1.02(0.16)$ & 0.85 & $-0.67(0.23)$ & $0.29(0.36)$ & 0.08 & $2.88 \pm 0.18$ & $0.09 \pm 0.02$ \\
\hline $\begin{array}{l}\text { Salaria } \\
\text { pavo }\end{array}$ & $15.82 \pm 2.87$ & $0.50 \pm 0.14$ & $0.53(0.21)$ & $1.00(0.34)$ & 0.45 & $-1.37(0.28)$ & $1.54(0.45)$ & 0.51 & $3.66 \pm 0.44$ & $0.10 \pm 0.02$ \\
\hline $\begin{array}{l}\text { Sparus } \\
\text { aurata }\end{array}$ & $23.89 \pm 2.72$ & $0.38 \pm 0.06$ & $0.46(0.29)$ & $1.56(0.5)$ & 0.52 & $-0.70(0.64)$ & $0.39(1.10)$ & 0.01 & $6.20 \pm 0.52$ & $0.10 \pm 0.02$ \\
\hline $\begin{array}{l}\text { Symphodus } \\
\text { cinereus }\end{array}$ & $20.14 \pm 2.91$ & $0.59 \pm 0.07$ & $0.58(0.11)$ & $0.88(0.13)$ & 0.80 & $-0.69(0.20)$ & $0.54(0.26)$ & 0.29 & $3.16 \pm 0.20$ & $0.10 \pm 0.01$ \\
\hline $\begin{array}{l}\text { Syngnathus } \\
\text { abaster }\end{array}$ & $2.05 \pm 0.25$ & $0.14 \pm 0.01$ & $0.50(0.21)$ & $0.82(0.84)$ & 0.49 & $-0.94(0.17)$ & $-0.34(0.69)$ & 0.20 & $3.53 \pm 0.32$ & $0.25 \pm 0.04$ \\
\hline
\end{tabular}


a $\mathrm{NH}_{4}{ }^{+}$excretion rates
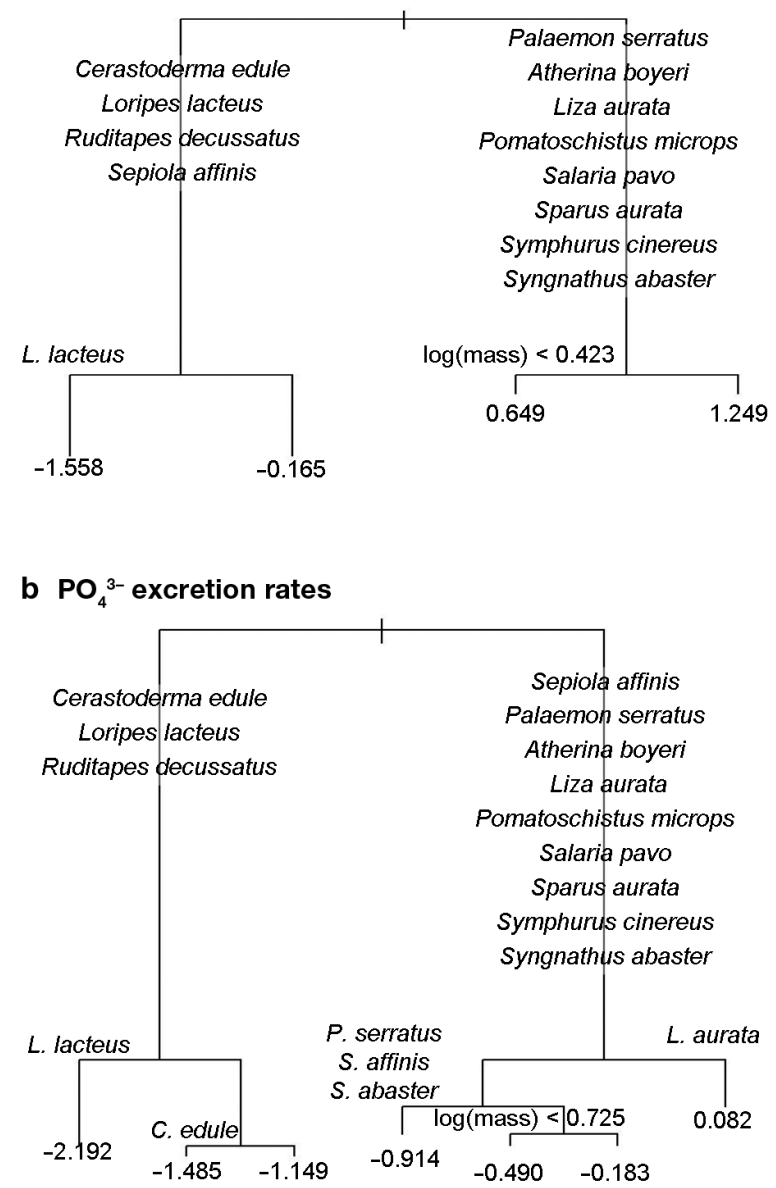

Fig. 2. Regression tree for (a) ammonium $\left(\mathrm{NH}_{4}^{+}\right)$and (b) phosphate $\left(\mathrm{PO}_{4}{ }^{3-}\right)$ excretion rates $\left(\log _{10}\right.$-transformed values). The mean for each sub-group is indicated

lower for the 3 bivalves, especially for Loripes lacteus. Among nektonic species, the mullet Liza aurata had higher rates than the 9 other species.

\section{DISCUSSION}

We found a significant effect of body mass on per capita excretion rates at the intraspecific level for most of the fishes but not for the 3 bivalve species. This finding may be explained by the small size range considered for mollusks, as previous studies found significant differences for other mollusk species (e.g. Arnott \& Vanni 1996). For fish, it would be of interest to assess excretion rates of adults of the 2 species studied only at their juvenile stage (i.e. thinlip mullet Liza ramada and gilthead seabream Sparus aurata) to assess whether this relationship stands across life stages.
We observed positive relations between body mass and excretion rates at the interspecific level, which confirm previous findings on fish (e.g. Torres \& Vanni 2007). However, these correlations were stronger when considering the 3 classes of invertebrates and fish than when considering only the 8 fish species. Indeed, the 3 bivalve species were smaller and had lower excretion rates than fish (Fig. 1). However, statistical analyses confirmed that the taxonomic factor was more discriminant than body mass itself (Table 3, Fig. 2).

Mean mass-specific excretion rates (Table 2) confirm this finding as fishes tend to have excretion rates per unit of mass $10 \times$ higher than mollusks for ammonium and $5 \times$ higher for phosphate. Therefore, at equivalent size, fishes are excreting more nutrients than mollusks do, while among fishes, Sparus aurata and juvenile Liza aurata have the highest mass-specific excretion rates for ammonium and phosphate, respectively. A study conducted in intertidal salt marsh creeks on the Atlantic USA coast also found that shrimps excrete lower nutrient levels per unit of mass than fishes (Haertel-Borer et al. 2004). More interestingly, the fish species excreting the highest level of ammonium per unit of mass, the pinfish Lagodon rhomboides, is functionally similar to $S$. aurata (i.e. a bentho-pelagic and invertivorous species), and the fish excreting the most phosphate, the Atlantic silverside Menidia menidia, is similar to Atherina boyeri (a pelagic and planktivorous species).

To go further it would be necessary to compare excretion rate differences from a bioenergetic perspective by accounting for $\mathrm{N}$ and $\mathrm{P}$ body concentrations and to compare them with food item composition (Vanni et al. 2002, Torres \& Vanni 2007). Indeed, excretion rates are driven by ecophysiological constraints and reflect the imbalance between $\mathrm{N}$ and $\mathrm{P}$ inputs from food and the demand on them for metabolism and growth. For instance, vertebrates tend to have a higher body $\mathrm{P}$ concentration than macroinvertebrates because of the high P content in bones (Elser et al. 1996). Even among fish species, strong differences exist across families with different anatomies and diets (Vanni et al. 2002, Hood et al. 2005). In addition, analyzing the biological causes of the differences in excretion rates also deserves investigation at the intraspecific level for species exhibiting marked ontogenetical changes affecting both diet and anatomy. In general, for the upscaling of excretion rates to the ecosystem functioning, it is necessary to assess whether body mass has an isometric or allometric effect on excretion for the different species (McIntyre et al. 2008). 
More generally, while the assessment of macrofauna excretion rates in the field and their upscaling is a necessary first step toward better understanding their contribution to nutrient recycling, the second step is to explicitly test the contribution of the different species through in situ (abundance manipulation) or ex situ (mesocosm) experiments. Such experiments would also offer the opportunity to assess the effect of translocation of nutrients by the movement of organisms', be they vertical between the sediment and the water column (Schaus \& Vanni 2000) or horizontal between different habitats (Meyer \& Schultz 1985).

Acknowledgements. We are grateful to Yves Collos, Emilie le Floc'h, and the IFREMER aquaculture station for key technical support. We are also grateful to Camille Albouy, Simon Blanchet, Sébastien Brosse, Frédérique Carcaillet, Rémy Ferrer, Domingo Flores-Hernandez, Maud Mouchet, Julia Ramos-Miranda, Francesca Rossi, and Jean-Antone Tomasini for their help in the field. This research was supported by a grant from the Ecosystèmes Marins Côtiers (ECOSYM) laboratory. We also thank 3 reviewers and the editor for their comments that helped us to improve this manuscript.

\section{LITERATURE CITED}

Aminot A, Kerouel R (2004) Hydrologie des écosystèmes marins: paramètres et analyses, Editions de l'Ifremer, Plouzané

Arnott DL, Vanni MJ (1996) Nitrogen and phosphorus recycling by the zebra mussel (Dreissena polymorpha) in the western basin of Lake Erie. Can J Fish Aquat Sci 53: 646-659

Barbier EB, Hacker SD, Kennedy C, Koch EW, Stier AC, Silliman BR (2011) The value of estuarine and coastal ecosystem services. Ecol Monogr 81:169-193

Bracken MES, Friberg SE, Gonzalez-Dorantes CA, Williams SL (2008) Functional consequences of realistic biodiversity changes in a marine ecosystem. Proc Natl Acad Sci USA 105:924-928

> Chassot E, Bonhommeau S, Dulvy NK, Melin F, Watson R, Gascuel D, Le Pape O (2010) Global marine primary production constrains fisheries catches. Ecol Lett 13:495-505

Cockcroft AC, McLachlan A (1993) Nitrogen budget for a high-energy ecosystem. Mar Ecol Prog Ser 100:287-299

Dame R, Dankers N, Prins T, Jongsma H, Smaal A (1991) The influence of mussel beds on nutrients in the western Wadden Sea and eastern Scheldt estuaries. Estuaries 14: $130-138$

Elser JJ, Dobberfuhl DR, MacKay NA, Schampel JH (1996) Organism size, life history, and N:P stoichiometry. BioScience 46:674-684

Elser JJ, Bracken MES, Cleland EE, Gruner DS and others (2007) Global analysis of nitrogen and phosphorus limitation of primary producers in freshwater, marine and terrestrial ecosystems. Ecol Lett 10:1135-1142

Fox J (2008) Applied regression analysis and generalized linear models. SAGE Publications, London
Friedman JH (2001) Greedy function approximation: a gradient boosting machine. Ann Stat 29:1189-1232

- Haertel-Borer SS, Allen DM, Dame RF (2004) Fishes and shrimps are significant sources of dissolved inorganic nutrients in intertidal salt marsh creeks. J Exp Mar Biol Ecol 311:79-99

> Hood JM, Vanni MJ, Flecker AS (2005) Nutrient recycling by two phosphorus-rich grazing catfish: the potential for phosphorus-limitation of fish growth. Oecologia 146: 247-257

Jalabert SSM, Martin MP, Renaud JP, Boulonne L, Jolivet C, Montanarella L, Arrouays D (2010) Estimating forest soil bulk density using boosted regression modelling. Soil Use Manag 26:516-528

> Layman CA, Allgeier JE, Rosemond AD, Dahlgren CP, Yeager LA (2011) Marine fisheries declines viewed upside down: human impacts on consumer-driven nutrient recycling. Ecol Appl 21:343-349

McIntyre PB, Flecker AS, Vanni MJ, Hood JM, Taylor BW, Thomas SA (2008) Fish distributions and nutrient cycling in streams: can fish create biogeochemical hotspots? Ecology 89:2335-2346

> Meyer JL, Schultz ET (1985) Migrating haemulid fishes as a source of nutrients and organic-matter on coral reefs. Limnol Oceanogr 30:146-156

Raffaelli D, Emmerson M, Solan M, Biles C, Paterson D (2003) Biodiversity and ecosystem processes in shallow coastal waters: an experimental approach. J Sea Res 49: 133-141

Schaus MH, Vanni MJ (2000) Effects of gizzard shad on phytoplankton and nutrient dynamics: role of sediment feeding and fish size. Ecology 81:1701-1719

> Solan M, Cardinale BJ, Downing AL, Engelhardt KAM, Ruesink JL, Srivastava DS (2004) Extinction and ecosystem function in the marine benthos. Science 306: $1177-1180$

> Torres LE, Vanni MJ (2007) Stoichiometry of nutrient excretion by fish: interspecific variation in a hypereutrophic lake. Oikos 116:259-270

> Vanni MJ (2002) Nutrient cycling by animals in freshwater ecosystems. Annu Rev Ecol Syst 33:341-370

Vanni MJ, Flecker AS, Hood JM, Headworth JL (2002) Stoichiometry of nutrient recycling by vertebrates in a tropical stream: linking species identity and ecosystem processes. Ecol Lett 5:285-293

Villéger S, Miranda JR, Hernandez DF, Mouillot D (2010) Contrasting changes in taxonomic vs. functional diversity of tropical fish communities after habitat degradation. Ecol Appl 20:1512-1522

> Waldbusser GG, Marinelli RL, Whitlatch RB, Visscher PT (2004) The effects of infaunal biodiversity on biogeochemistry of coastal marine sediments. Limnol Oceanogr 49:1482-1492

Whiles MR, Huryn AD, Taylor BW, Reeve JD (2009) Influence of handling stress and fasting on estimates of ammonium excretion by tadpoles and fish: recommendations for designing excretion experiments. Limnol Oceanogr Methods 7:1-7

Worm B, Barbier EB, Beaumont N, Duffy JE and others (2006) Impacts of biodiversity loss on ocean ecosystem services. Science 314:787-790

Wright PA (1995) Nitrogen excretion: three end products, many physiological roles. J Exp Biol 198:273-281 